\title{
ARTICLE
}

Cite this: DOI: 10.1039/xoxxooooox

Received ooth January 2012, Accepted ooth January 2012

DOI: 10.1039/xoxxooooox

www.rsc.org/

\section{Nanoscale Engineering of Low-Fouling Surfaces through Polydopamine Immobilisation of Zwitterionic Peptides}

\author{
Jiwei Cui, Yi Ju, Kang Liang, Hirotaka Ejima, Samuel Lörcher, Katelyn T. Gause, \\ Joseph J. Richardson and Frank Caruso*
}

\begin{abstract}
We report a versatile appoach for the design of substrate-independent low-fouling surfaces via mussel-inspired immobilisation of zwitterionic peptides. Using mussel-inspired polydopamine (PDA) coatings, zwitterionic glutamic acid- and lysine-based peptides were immobilised on various substrates, including noble metals, metal oxides, polymers, and semiconductors. The variation of surface chemistry and surface wettability upon surface treatment was monitored with X-ray photoelectron spectroscopy (XPS) and water contact angle measurements. Following peptide immobilisation, the surfaces became more hydrophilic due to the strong surface hydration compared with PDA-coated surfaces. The peptide-functionalised surfaces showed resistance to human blood serum adsorption and also effectively prevented the adhesion of gram-negative and gram-positive bacteria (i.e., Escherichia coli and Staphylococcus epidermidis) and mammalian cells (i.e., NIH 3T3 mouse embryonic fibroblast cells). The versatility of mussel-inspired chemistry combined with the unique biological nature and tunability of peptides allows for the design of low-fouling surfaces, making this a promising coating technique for various applications.
\end{abstract}

\section{Introduction}

The design of low-fouling surfaces to resist nonspecific attachment of biomolecules, microorganisms and mammalian cells is fundamental for biomedical applications, such as drug delivery, ${ }^{1}$ biosensing, ${ }^{2}$ and medical implant coatings. ${ }^{3}$ Immobilising poly(ethylene glycol) (PEG) is one of the most commonly used approaches to impart adhesion resistance to a surface. ${ }^{4,5}$ However, PEG-based materials are susceptible to oxidation in many biochemically relevant solutions, which leads to a loss of adsorption resistance. ${ }^{6-8}$ Several alternatives to PEG-based materials, including biological polymers such as polysaccharides and polypeptoids, and synthetic polymers such as poly(acrylamide) and poly(hydroxypropyl methacrylate), have been reported over the past decade. ${ }^{9}$ Most of these materials are protein resistant but may not resist bacteria or mammalian cell attachment, subsequently resulting in biofilm formation. ${ }^{10}$ Therefore, it is highly desirable to design surfaces that are resistant to both protein and cell attachment for biomedical applications.

In recent years, zwitterionic materials have attracted great interest in biomedical applications due to their ultra-low fouling properties. ${ }^{11}$ Zwitterionic synthetic polymers, such as poly(carboxybetaine) and poly(sulfobetaine), have shown to be highly resistant to nonspecific protein adsorption, bacteria adhesion, and biofilm formation. ${ }^{12-16}$
Amino acids, natural zwitterions, have also shown low-fouling properties. ${ }^{17,18}$ Jiang and coworkers reported the formation of ultralow-fouling peptide self-assembled monolayers composed of alternating negatively and positively charged residues, glutamic acid (E) and lysine (K), respectively, which are major candidates for biodegradable nonfouling materials. ${ }^{19,20}$ The unique biological and tuneable nature of peptides has made them promising low-fouling biomaterials for biomedical applications. ${ }^{21}$ However, there are few studies on the low-fouling performance of zwitterionic peptides, and current peptide coating methods are limited to gold surfaces, thus restricting applicability. A universal method for immobilising zwitterionic peptides on a diverse range of materials is desirable for the preparation of low-fouling surfaces.

The introduction of desired properties onto virtually any material surface is an ultimate goal in surface chemistry. Inspired by the adhesive properties of the composition (catechol groups) of mussel proteins, Messersmith and coworkers introduced a facile approach to form polydopamine (PDA) films on a wide range of substrates via dopamine self-polymerisation. ${ }^{22}$ Additionally, secondary reactions (i.e., Michael addition or Schiff base formation) can be used to create a variety of covalently grafted functional layers. ${ }^{23-26}$ We have previously reported that mussel-inspired chemistry can also be applied to both solid and liquid templates for the preparation of PDA 
capsules. $^{27-29}$ The obtained capsules can be further loaded with polymer-drug conjugates via Michael addition reaction for drug delivery. ${ }^{30}$ Furthermore, PDA shows excellent biocompatibility and low cytotoxicity, making it a versatile platform for biomedical applications. ${ }^{31,32}$ Although mussel mimetic initiators have been used to prepare low-fouling zwitterionic polymer surfaces, ${ }^{33-36}$ research on PDA-based zwitterionic materials is limited and there are no reports of immobilising zwitterionic peptides based on musselinspired chemistry. Therefore, a strategy to combine facile and reactive PDA coatings with the low-fouling nature of zwitterionic peptides would improve the potential of these materials for the formation of low-fouling surfaces and related applications.

In this study, we report a substrate-independent modification for the assembly of low-fouling surfaces based on mussel-inspired chemistry, which is used for the subsequent immobilisation of zwitterionic peptides with a sequence of EKEKEKEPPPPC (Scheme 1). This peptide, with an amine $\mathrm{N}$-terminus and an amidated $\mathrm{C}$ terminus, has an overall neutral charge and an extended polyproline helix conformation. ${ }^{20}$ X-ray photoelectron spectroscopy (XPS) measurements proved that the PDA films can be formed on various substrates (e.g., noble metals, metal oxides, polymers, and semiconductors) and could serve as the anchoring layer for subsequent grafting of zwitterionic peptides via Michael addition between thiol and quinone groups. The water contact angle of surfaces decreased after peptide immobilisation compared with that of PDA-coated surfaces due to the electrostatically-induced hydration of the peptide. The peptide-functionalised surfaces showed resistance to human blood serum adsorption. In addition, these surfaces also resisted bacteria and mammalian cell adhesion. The substrate-independent mussel-inspired immobilisation of zwitterionic peptides for the design of low-fouling surfaces provides a promising method for various applications, including drug delivery, biosensing and medical implants.

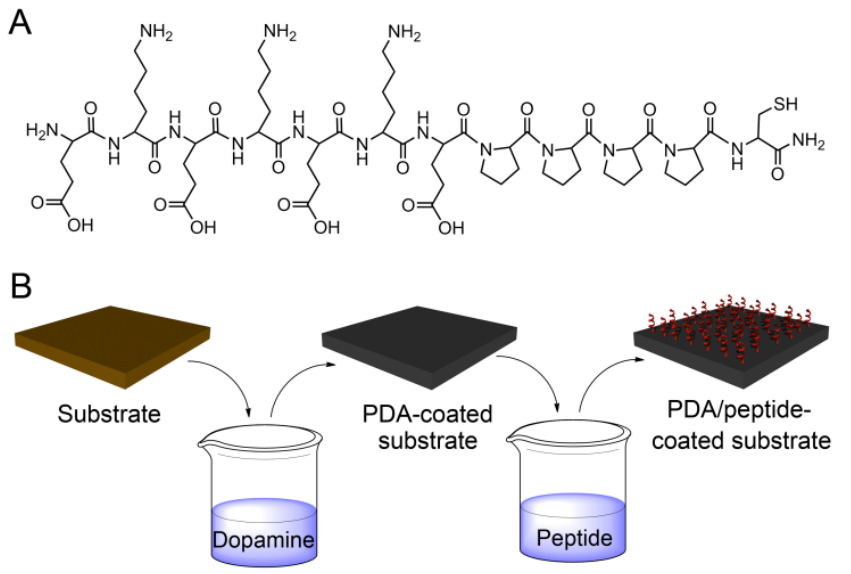

Scheme 1. (A) Molecular structure of the zwitterionic peptide with the sequence EKEKEKEPPPPC. (B) Schematic illustration of a twostep approach to prepare low-fouling films on a variety of substrates, including aluminum oxide, gold, tetrafluoroethylene, polystyrene, and glass.

\section{Experimental}

\section{Materials}

Tris(hydroxymethyl)aminomethane (Tris) and 3hydroxytyramine hydrochloride (dopamine) were obtained from Sigma-Aldrich (Australia). Methoxy-poly(ethylene glycol)-thiol (PEG, $5 \mathrm{kDa}$ ) was purchased from JenKem Technology USA (China). The peptide of EKEKEKEPPPPC was obtained from GL Biochem Ltd. (China). Dulbecco's Phosphate-Buffered Saline (DPBS), Luria Broth base (miller's LB broth base), Calcein AM, and LIVE/DEAD BacLight Bacterial Viability Kit L7012 containing SYTO 9 and propidium iodide dyes were purchased from Molecular Probes (Australia). Bacteriological agar was obtained from Scientifix (Australia). HBS was separated from whole human blood (Human Research and Ethics Committee approval was obtained for all studies of human samples and informed signed consent was obtained from the subjects). The water used in all experiments was prepared in a three-stage Millipore Milli-Q Plus 185 purification system and had a resistivity greater than $18 \mathrm{M} \Omega \mathrm{cm}$. The $\mathrm{pH}$ values of all solutions were measured with a Mettler-Toledo MP220 pH meter. All of the solutions were filtered using syringe filters with $0.2 \mu \mathrm{m}$ diameter pores before use.

\section{Substrate Preparation}

Gold-coated silicon wafers, $\mathrm{Al}_{2} \mathrm{O}_{3}$ foil and glass slides were cleaned with Piranha solution ( $7: 3 \mathrm{v} / \mathrm{v}$ mixture of concentrated sulfuric acid and $30 \%$ hydrogen peroxide) for $30 \mathrm{~min}$, rinsed with water and dried with nitrogen gas before use. Caution! Piranha solution is extremely corrosive and reacts violently with organic materials. It should be handled with great care. Polytetrafluoroethylene (PTFE) and polystyrene (PS) substrates were cleaned with 2-propanol and sonication, rinsed with water, and dried with nitrogen before use.

\section{Polydopamine Coating and Peptide Functionalisation of Substrates}

Dopamine was dissolved in $10 \mathrm{mM}$ Tris buffer $(\mathrm{pH}$ 8.5). Substrates were immersed in the dopamine solution with a concentration of $2 \mathrm{mg} \mathrm{mL}^{-1}$ for $4 \mathrm{~h}$. The coated substrates were rinsed with water and $50 \mathrm{mM}$ Tris buffer $(\mathrm{pH}$ 8.5), and subsequently immersed in $5 \mathrm{mg} \mathrm{mL} \mathrm{m}^{-1}$ of peptide or PEG solution (50 mM Tris buffer, $\mathrm{pH} 8.5$ ) for overnight incubation. The obtained substrates were rinsed with water and dried with nitrogen. 8-well chambered glass slides (culture area $0.7 \mathrm{~cm}^{2}$, Thermo Scientific) were coated with PDA or PDA/peptide for cell experiments. The Tris buffer was degassed with nitrogen for $1 \mathrm{~h}$ before use to prevent oxidation to disulfide bonds (-S-S) between the terminating thiol groups of the peptide.

\section{X-ray Photoelectron Spectroscopy (XPS) Analysis}

XPS spectra were acquired using a VG ESCALAB220i-XL spectrometer equipped with a hemispherical analyser. The 
incident radiation was monochromatic Al Ka X-rays (1486.6 $\mathrm{eV})$ at $220 \mathrm{~W}(22 \mathrm{~mA}$ and $10 \mathrm{kV}$ ). Survey (wide) and high resolution (narrow) scans were taken at analyser pass energies of $100 \mathrm{eV}$ and $50 \mathrm{eV}$, respectively. Survey scans were carried out over 0-1200 eV binding energy range with $1.0 \mathrm{eV}$ step size and $100 \mathrm{~ms}$ dwell time. Narrow high resolution scans were run over a $20 \mathrm{eV}$ binding energy range with a $0.05 \mathrm{eV}$ step size and a $250 \mathrm{~ms}$ dwell time. Base pressure in the analysis chamber was below $8.0 \times 10^{-9}$ mbar. A low energy flood gun was used to compensate the surface charging effect. All data were processed using CasaXPS software and the energy calibration was referenced to the $\mathrm{C} 1 s$ peak at $285.0 \mathrm{eV}$.

\section{Contact Angle Measurements}

The water contact angle of the substrates, PDA-coated substrates, and PDA/peptide-coated substrates was measured using a Model 200 standard goniometer (Ramé-Hart, USA.). All contact angles were measured with a $10 \mu \mathrm{L}$ water droplet at ambient temperature. The recorded contact angles are averages of three measurements made on different areas of the surface.

\section{Quartz Crystal Microbalance (QCM) Measurements of Protein Adsorption}

QCM chips were coated ex-situ with PDA by dropping the dopamine solution onto the chips. (Ex-situ preparation of the PDA surfaces was performed to prevent blocking of the QCM channels by PDA aggregates that form.) After $4 \mathrm{~h}$ coating, the chips were washed with water and dried with nitrogen. Peptide or PEG was immobilised on the PDA-coated chips by the same dropping method (overnight). To prevent evaporation of the solution, the chips were sealed in a petri dish. The PEG and peptide coverage, and peptide stability were assessed using a QCM-D E4 device with four flow cells (Q-Sense AB, Västra, Frölunda, Sweden). Nonspecific adsorption of HBS ( $\mathrm{pH}$ 7.4) on the chips was checked after 15 min of adsorption. An inhouse-built QCM device with a frequency counter from Agilent was used to determine the film mass after peptide immobilisation and HBS adsorption. ${ }^{37}$ The piezoelectric quartz crystal changes its fundamental oscillation frequency, $F_{o}$, as mass is deposited onto (or depleted from) the surface. According to the Sauerbrey equation, the resonant frequency shift, $\triangle F$, of a QCM is proportional to the mass change, $\Delta m$ :

$\Delta F=-\frac{2 F_{o}^{2}}{A\left(\mu_{q} \rho_{q}\right)^{1 / 2}} \Delta m$

where $\mu_{q}$ is the shear modulus of the quartz $\left(2.947 \times 10^{13} \mathrm{~g} \mathrm{~m}^{-1} \mathrm{~s}\right.$ $\left.{ }^{2}\right), \rho_{q}$ is the density of the quartz $\left(2.648 \times 10^{6} \mathrm{~g} \mathrm{~m}^{-3}\right), F_{o}$ is the operating frequency of the crystals $\left(9 \times 10^{6} \mathrm{~Hz}\right)$, and $A$ is the piezoelectric area of the electrode. The QCM electrodes from Kyushu Dentsu were gold coated on both sides and have a diameter of $4.5 \mathrm{~mm}$.

\section{Bacteria Adhesion Assay}

For quantitative evaluation, the concentration of bacteria was calculated by counting the colony forming units (CFU) on an LB agar plate, which is consistent with the counts obtained from flow cytometry. To check the bacteria adhesion on glass, glass/PDA, and glass/PDA/peptide systems, $300 \mu \mathrm{L}$ of an Escherichia coli (E. coli, ATCC \#14948) or Staphylococcus epidermidis ( $S$. epidermidis, ATCC \#14990) suspension in

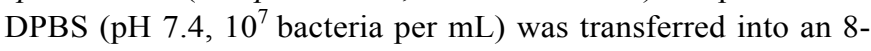
well chambered glass slides. After $24 \mathrm{~h}$ incubation at $37^{\circ} \mathrm{C}$, the bacteria on different substrates were stained with SYTO 9 dye ( $2 \mu \mathrm{L}$ of dye diluted with $200 \mu \mathrm{L}$ of DPBS) for $5 \mathrm{~min}$. Each well was gently rinsed with DPBS. The adhesion and morphology of the bacteria were observed under a fluorescence microscope. The number of bacteria present in microscopy images $(60 \times$ objective magnification) was analysed by Image $\mathbf{J}$ software.

\section{Mammalian Cell Attachment on Substrates}

NIH 3 T3 mouse embryonic fibroblast cells (ATCC CRL-2752) were maintained at $37{ }^{\circ} \mathrm{C}$ with $5 \% \mathrm{CO}_{2}$ in Dulbecco's Modified Eagles' Medium (DMEM) containing $10 \%(\mathrm{v} / \mathrm{v})$ of fetal bovine serum (FBS) and $1 \%(\mathrm{v} / \mathrm{v})$ of glutamax (Invitrogen). Prior to cell attachment experiments, an 8-well chambered glass slides was rinsed with copious amounts of DPBS. Each well (glass, glass/PDA and glass/PDA/peptide substrates) was seeded with $3 \times 10^{4}$ cells in DMEM (pH 7.4). After $24 \mathrm{~h}$ or $72 \mathrm{~h}$ incubation at $37{ }^{\circ} \mathrm{C}$ in $5 \% \mathrm{CO}_{2}$ and $100 \%$ relative humidity, unattached cells were removed by gently washing with DPBS, and the cells on different substrates were stained with $200 \mu \mathrm{L}$ of Calcein AM solution for $5 \mathrm{~min}(1 \mu \mathrm{L}$ of dye with a concentration of $1 \mathrm{mg}$ $\mathrm{mL}^{-1}$ diluted with $1 \mathrm{~mL}$ of DPBS). Finally, each well was gently rinsed with DPBS. The attachment and morphology of the cells was observed using fluorescence microscopy. The number of attached cells was determined by visually counting cells present in the microscopy images (10× objective magnification).

\section{Fluorescence Microscopy}

Fluorescence microscopy images were taken using an Olympus IX71 inverted fluorescence microscope equipped with a DIC slider (UDICT, Olympus), the corresponding filter sets, and different immersion objectives (Olympus UPFL20/0.5NA, W.D. 1.6).

\section{Atomic Force Microscopy (AFM)}

AFM images were acquired with a NanoWizard II AFM (JPK Instruments, Berlin, Germany) in intermittent contact. Film thickness and roughness were analysed using JPK SPM Image Processing software (V.4.4.28).

\section{Results and discussion}

\section{Immobilisation of Zwitterionic Peptides}


Mussel-inspired surface chemistry has proven to be a versatile and substrate-independent approach to form polymer coatings with tuneable film thickness, ${ }^{38-40}$ while still allowing for the formation of multifunctional adlayers. ${ }^{41}$ For the immobilisation of zwitterionic peptides, PDA films were first coated on different substrates, including aluminum oxide $\left(\mathrm{Al}_{2} \mathrm{O}_{3}\right)$, gold $(\mathrm{Au})$, polytetrafluoroethylene (PTFE), polystyrene (PS), and glass $\left(\mathrm{SiO}_{2}\right)$, simply through dip-coating the objects in an aqueous solution of dopamine for $4 \mathrm{~h}$. The PDA-coated
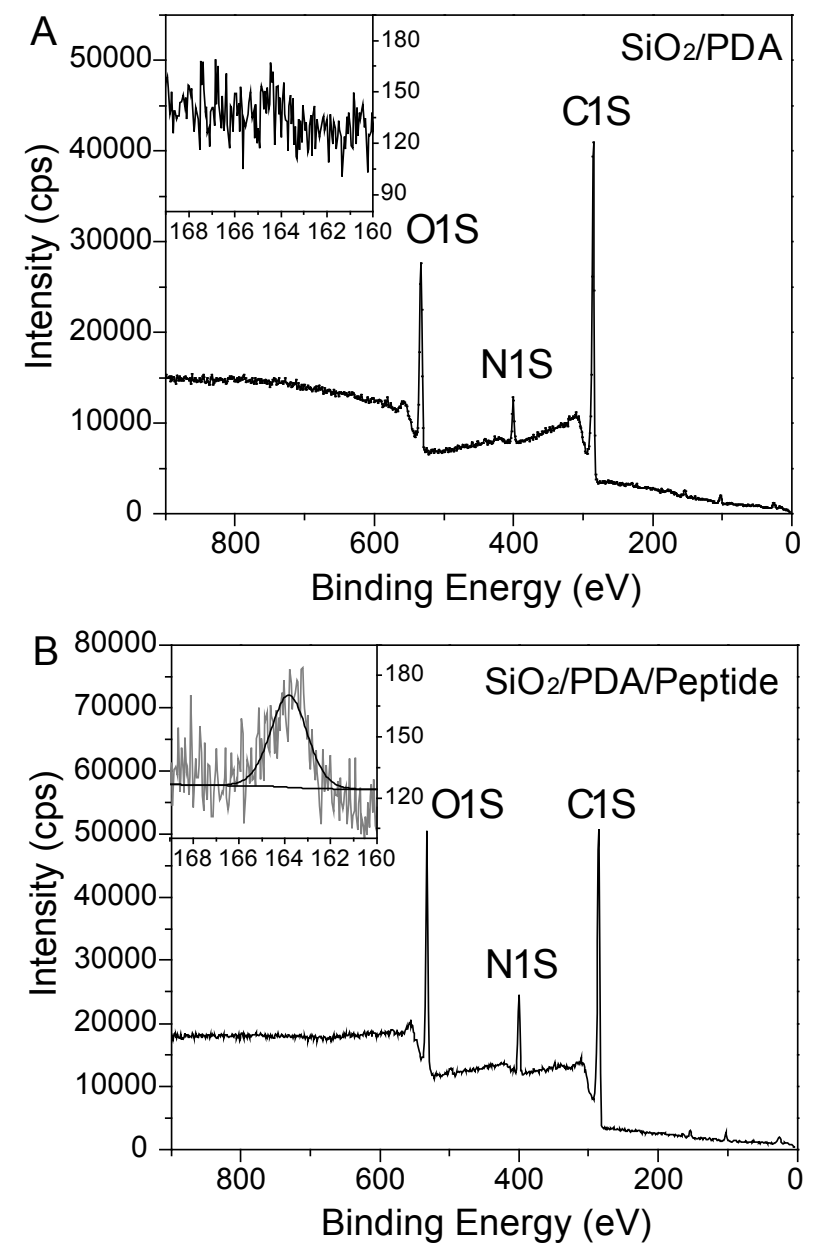

Fig. 1 XPS characterisation of (A) PDA-coated and (B) PDA/peptide-coated glass. The photoelectron peaks at $285 \mathrm{eV}$, $400 \mathrm{eV}$ and $533 \mathrm{eV}$ represent carbon, nitrogen and oxygen, respectively. Insets show the high-resolution spectra. The peak at $164 \mathrm{eV}$ represents the sulphur $2 \mathrm{p}$ signal derived from the surface-immobilised peptide.

substrates were subsequently immersed in peptide solution for overnight incubation. AFM measurements showed the average thickness of PDA and PDA/peptide films were about $15 \mathrm{~nm}$ and $17 \mathrm{~nm}$, respectively, and did not significantly change before and after peptide coating (Fig. S1). However, the surface became smoother after peptide coating, where the root-meansquared (RMS) roughness changed from $4.2 \mathrm{~nm}$ to $2.2 \mathrm{~nm}$. To further confirm the PDA coating and peptide immobilisation, XPS was used to monitor the variation of the surface chemistry on the surfaces. Fig. 1 shows the XPS spectra of a glass substrate after PDA coating and peptide immobilisation. After the treatment with dopamine solution, the silicon peak from the underlying glass substrates was screened, indicating that the surfaces were coated with a film that was thicker than the analysis depth of XPS ( $\sim 10 \mathrm{~nm})$. The nitrogen-to-carbon signal ratio $(\mathrm{N} / \mathrm{C})$ of 0.116 was similar to that of the theoretical value for dopamine $(\mathrm{N} / \mathrm{C}=0.125)$, implying the formation of a polydopamine layer. After peptide treatment, the nitrogen-tocarbon signal ratio increased to 0.196 , which is between the theoretical values for dopamine and peptide $(\mathrm{N} / \mathrm{C}=0.262)$. In addition, the peak at $164 \mathrm{eV}$ in the high-resolution spectrum represents the sulphur $2 p$ signal, indicating the successful immobilisation of the peptide, which is based on the Michael addition between the thiol group (cysteine) on the peptide and quinone groups on the PDA films. ${ }^{42}$ Similarly, the variations in the surface chemistry observed on the other surfaces (i.e., $\mathrm{Al}_{2} \mathrm{O}_{3}, \mathrm{Au}, \mathrm{PTFE}$, and PS) also indicate successful PDA coating and peptide functionalisation (Fig. S2).

\section{Wetting of the Peptide-Functionalised Surfaces}

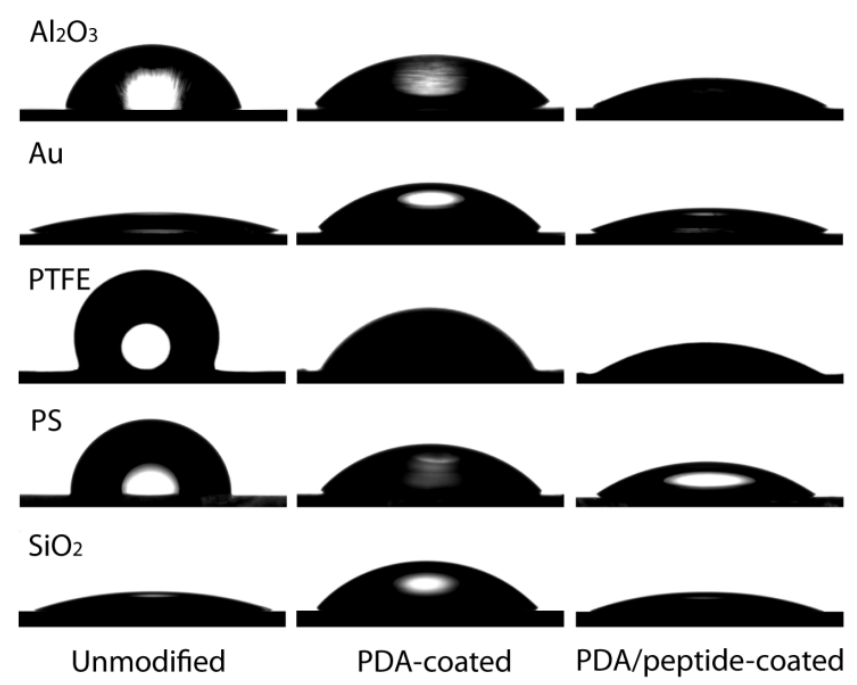

Fig. 2 Images of water droplets on several nonmodified (left), PDA-coated (middle), and PDA/peptide-coated (right) substrates. Substrates investigated include $\mathrm{Al}_{2} \mathrm{O}_{3}, \mathrm{Au}$, PTFE, $\mathrm{PS}$, and $\mathrm{SiO}_{2}$. Contact angle values are shown in Table $\mathrm{S} 1$.

The surface wettability upon surface treatment was examined by water contact angle measurements. Fig. 2 shows the variation of the water contact angle during the interfacial nanoengineering of various substrates. Contact angle values are shown in Table S1. After PDA modification, water contact angles on all hydrophobic or hydrophilic substrates converged from their widely ranging pristine values to near $50^{\circ}$, which approached the theoretical value of the PDA film as reported elsewhere. ${ }^{43}$ Although there were some deviations of the measured contact angles on different surfaces, which were probably caused by surface roughness, ${ }^{44}$ all of the modified surfaces exhibited 
similar relative hydrophilicity. The surfaces with the immobilised peptides became more hydrophilic, with contact angles between $20^{\circ}$ $30^{\circ}$, which indicates that stronger surface hydration occurs at the peptide-modified surfaces. For a control experiment, $\mathrm{Au}$ and $\mathrm{Al}_{2} \mathrm{O}_{3}$ substrates were immersed in peptide solution for overnight incubation. The contact angle of the Au/peptide surface was $20^{\circ}$, which is similar to that of the $\mathrm{Au}$ and $\mathrm{Au} / \mathrm{PDA} /$ peptide surfaces. However, the contact angle of the $\mathrm{Al}_{2} \mathrm{O}_{3}$ /peptide surface was $70^{\circ}$, which is considerably larger than that of the $\mathrm{Al}_{2} \mathrm{O}_{3} / \mathrm{PDA} /$ peptide surface (Table S1). This indicates that the peptide could not be efficiently immobilised on $\mathrm{Al}_{2} \mathrm{O}_{3}$ surfaces without a PDA coating.

\section{Protein Adsorption Resistance}

Surface hydration is generally considered the key to nonspecific protein adsorption resistance, as a tightly bound water layer forms a physical and energetic barrier to prevent protein adsorption to the surface. ${ }^{45-47}$ Zwitterionic materials contain both positively and negatively charged moieties, and can bind water molecules firmly and stably via electrostatically-induced hydration. ${ }^{48}$ Since the peptide-functionalised surfaces showed strong hydration, it was of interest to characterise the lowfouling nature of the surfaces.

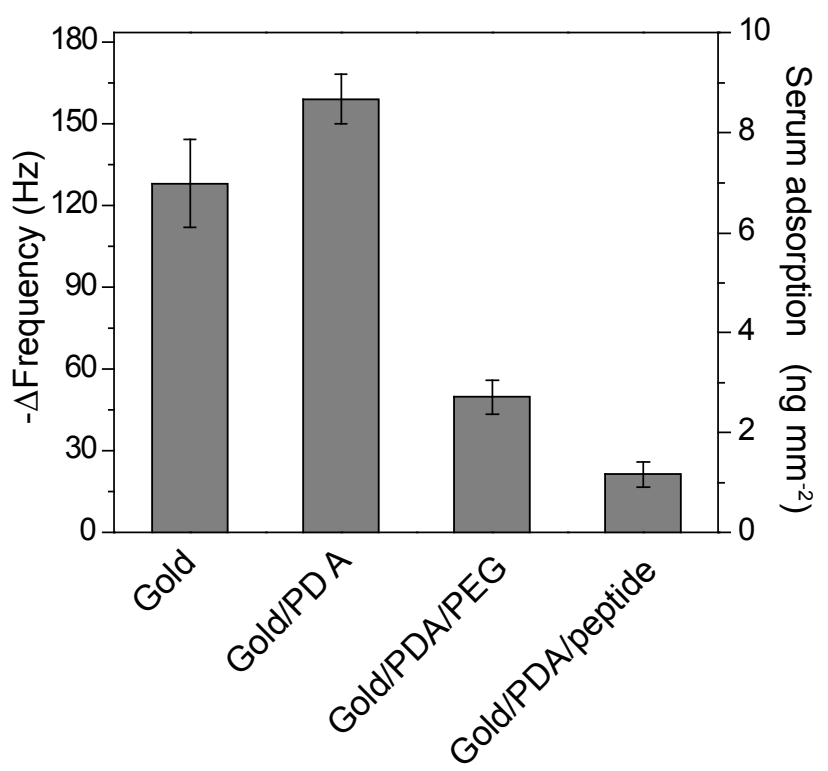

Fig. 3 Adsorption of HBS onto Au, Au/PDA, Au/PDA/PEG and $\mathrm{Au} / \mathrm{PDA} /$ peptide surfaces on planar supports, monitored by QCM. The substrates were washed with water after incubation in HBS (undiluted, $15 \mathrm{~min}$ ) and the frequency changes due to protein adsorption were measured.

To assess the ability of the peptide-functionalised surfaces to resist the adsorption of fouling proteins, peptide-functionalised gold chips were incubated with undiluted human blood serum (HBS). For comparison, nonmodified gold chips, gold chips coated with PDA, and PDA/PEG-functionalised gold chips were also incubated with HBS. Herein we chose PEG as a control because it is widely used to prevent protein fouling. PEG functionalisation was performed according to a procedure described elsewhere. ${ }^{22}$ After incubation, the chips were rinsed with water to remove unbound HBS proteins, dried with nitrogen and finally the protein adsorption amount was quantified with quartz crystal microbalance (QCM). The PEG and peptide coverage, examined by QCM, was 82 and $156 \mathrm{ng}$ $\mathrm{cm}^{-2}$, respectively, which indicates that the immobilisation of peptide is more efficient. It is noted that the peptide coverage does not change when the peptide concentration is above $1 \mathrm{mg}$ $\mathrm{mL}^{-1}$. Fig. 3 shows the fouling behaviour of the different surfaces after $15 \mathrm{~min}$ incubation with HBS. The frequency change corresponds to the relative amount of protein adsorbed. Gold surfaces showed a decrease in QCM frequency of $128 \mathrm{~Hz}$, indicating an increase in mass due to large amount of protein adsorption $\left(\sim 7.0 \mathrm{ng} \mathrm{mm}^{-2}\right)$. PDA-coated gold surfaces provided higher protein fouling properties $\left(\sim 8.7 \mathrm{ng} \mathrm{mm} \mathrm{mm}^{-2}\right)$, which was expected, as PDA has been used to effectively immobilise proteins on different substrates. ${ }^{49}$ After the immobilisation of the peptide onto the PDA-coated gold surfaces, there was a significantly smaller amount of protein adsorbed $\left(\sim 1.1 \mathrm{ng} \mathrm{mm}^{-}\right.$ $\left.{ }^{2}\right)$. The peptide-functionalised surfaces were more than two times more resistant to protein adsorption than PEGfunctionalised surfaces $\left(\sim 2.7 \mathrm{ng} \mathrm{\textrm {mm } ^ { - 2 }}\right)$. After $24 \mathrm{~h}$ incubation with HBS, serum adsorption increased by a factor of two on the peptide-modified surfaces, which is lower than that of PEGmodified surface after 15 min incubation with HBS. A possible explanation for this could be that the zwitterionic peptides have higher surface hydration, induced by ionic solvation, when compared to the hydrogen bonding-induced hydration of PEGfunctionalised surfaces. 

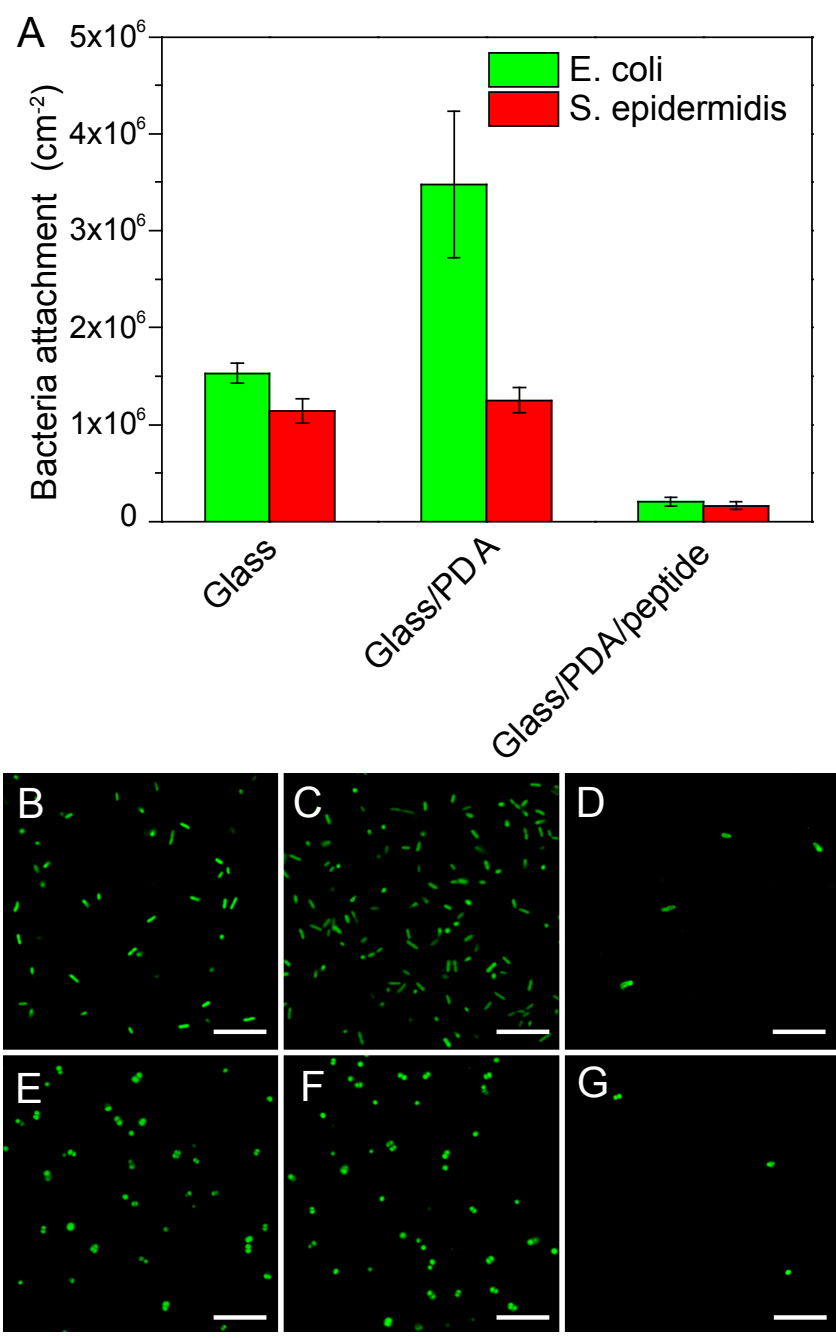

Fig. 4 (A) Quantitative E. coli and S. epidermidis adhesion onto glass, glass/PDA and glass/PDA/peptide substrates after incubation for $24 \mathrm{~h}$. Representative fluorescence microscopy imges of (B-D) E. coli and (E-G) S. epidermidis adhesion on $(\mathrm{B}, \mathrm{E})$ glass, $(\mathrm{C}, \mathrm{F})$ glass/PDA, and $(\mathrm{D}, \mathrm{G})$ glass/PDA/peptide substrates. All scale bars are $10 \mu \mathrm{m}$.

\section{Resistance to Bacteria Adhesion}

To further examine the low-fouling properties of peptidefunctionalised surfaces, two different strains of bacteria, Escherichia coli (E. coli) and Staphylococcus epidermidis ( $S$. epidermidis), were seeded into an 8-well chambered glass slide, which had been coated with PDA and subsequently immobilised with zwitterionic peptides. As a control, bacteria were also incubated in nonmodified and PDA-coated glass slides. After $24 \mathrm{~h}$ incubation, the bacteria were stained with SYTO 9 dye. Each well was gently rinsed with Dulbecco's Phosphate Buffered Saline (DPBS) to remove the free dye and unbound bacteria. The adhesion and morphology of the bacteria were observed and quantified by fluorescence microscopy.

Fig. 4A shows the number of attached bacteria on the different surfaces (glass, glass/PDA, and glass/PDA/peptide).
The gram-positive $S$. epidermidis resulted in similar adhesion on nonmodified glass and PDA-coated glass: $\sim 1.1 \times 10^{6}$ and $\sim 1.2 \times 10^{6}$ bacteria per $\mathrm{cm}^{2}$, respectively. However, the gramnegative $E$. coli showed greater adsorption on PDA surfaces $\left(\sim 3.5 \times 10^{6}\right.$ bacteria per $\left.\mathrm{cm}^{2}\right)$ compared with nonmodified glass $\left(\sim 1.5 \times 10^{6}\right.$ bacteria per $\left.\mathrm{cm}^{2}\right)$. Following peptide immobilisation, the adhesion of E. coli $\left(\sim 2.0 \times 10^{5}\right.$ bacteria per $\left.\mathrm{cm}^{2}\right)$ and $S$. epidermidis $\left(\sim 1.6 \times 10^{5}\right.$ bacteria per $\left.\mathrm{cm}^{2}\right)$ were significantly reduced about 10 times, which is shown in the fluorescence images (Fig. 4 B-G). Compared with PEGmodified surfaces, peptide-modified surfaces have a similar resistance to $E$. Coli adhesion; however, the peptide-modified surfaces are four times more resistant to $S$. epidermidis adhesion (Fig. S3). These results clearly demonstrate that the peptide-functionalised surfaces are low-fouling, effectively preventing biological adhesion of both gram-positive and gramnegative bacteria.

\section{Resistance to Mammalian Cell Attachment}

Some low-fouling materials are protein and bacteria resistant, but may not resist the attachment of mammalian cells. Since the surfaces immobilised with zwitterionic peptides resisted HBS and bacteria adhesion, it was of interest to determine whether peptide-functionalised surfaces possessed the same ability to resist the attachment of mammalian cells. Here, NIH 3T3 mouse embryonic fibroblast (3T3) cells were used to examine the low-fouling properties of the peptide-functionalised surfaces (Fig. 5). Similar to the bacteria adhesion experiments, nonmodified glass slides and PDA-coated glass slides were used as controls. For the nonmodified glass slides, the cell coverage of the available surface area was about $3.6 \times 10^{4}$ cells per $\mathrm{cm}^{2}$. In contrast, the PDA-coating promoted cell attachment, which showed a 3-fold increase in mammalian cell attachment compared with nonmodified glass slides. After $72 \mathrm{~h}$ incubation, cell attachment increased on both the nonmodified glass slides and the PDA-coated glass slides. 3T3 cells were found to cover the majority of the available PDA-coated surface (Fig. 5F). However, even after $72 \mathrm{~h}$ incubation, 3T3 cells were barely observed on the peptide-functionalised surfaces. Quantitatively, adhered cell densities on the peptidefunctionalised surfaces were reduced by $92 \%$ after $24 \mathrm{~h}$ and $95 \%$ after $72 \mathrm{~h}$ compared with the nonmodified glass slides, which is similar to the PEG-functionalised surfaces. These results indicate that peptide-functionalised surfaces not only resist protein adsorption but also both bacteria and mammalian cell attachment, which suggests that the mussel-inspired immobilisation of zwitterionic peptides can be an important foundation for the future design of material-independent lowfouling surfaces. 

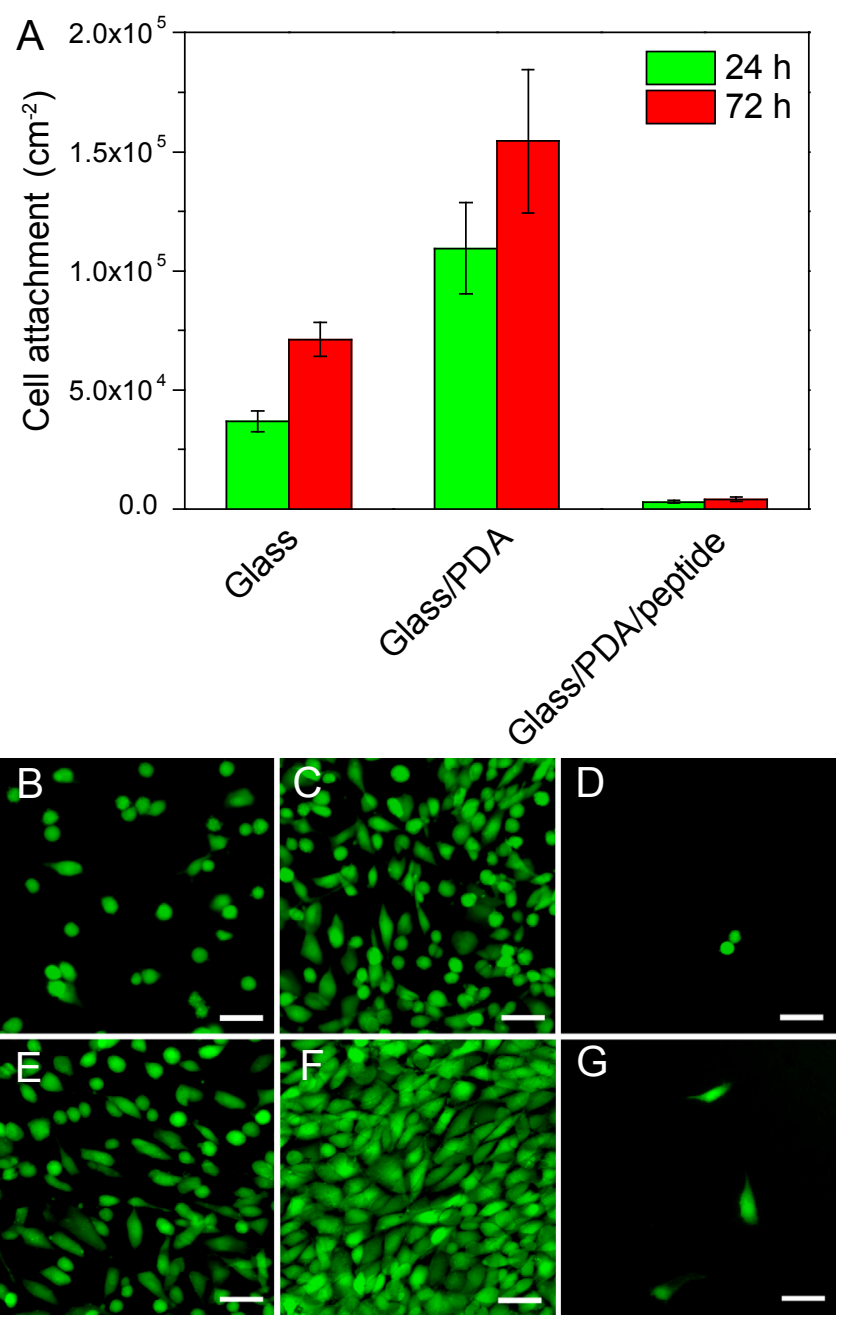

Fig. 5 (A) Quantitative $3 \mathrm{~T} 3$ fibroblast cell attachment onto glass, glass/PDA and glass/PDA/peptide substrates after incubation for $24 \mathrm{~h}$ and $72 \mathrm{~h}$. Fluorescence microscopy images of 3 T3 fibroblast cell attachment on (B, E) glass, (C, F) glass/PDA, and (D, G) glass/PDA/peptide substrates after incubation for (B-D) $24 \mathrm{~h}$ and (E-G) $72 \mathrm{~h}$. All scale bars are 50 $\mu \mathrm{m}$.

\section{Conclusions}

In summary, we have reported a versatile appoach for the design of low-fouling surfaces on different substrates via the mussel-inspired immobilisation of zwitterionic peptides based on the EK sequence. PDA coating on various substrates (i.e., $\mathrm{Al}_{2} \mathrm{O}_{3}, \mathrm{Au}$, PTFE, PS, and $\mathrm{SiO}_{2}$ ) and the subsequent immobilisation of the peptides were proven by XPS measurements. Following peptide immobilisation, the surfaces became more hydrophilic compared with PDA-coated surfaces, indicating that strong surface hydration occurred at the peptidemodified surfaces. The peptide-functionalised surfaces showed significant resistance to protein adsorption. Furthermore, these surfaces could effectively prevent the biological adhesion of bacteria and mammalian cells. In addition, the low-fouling effect is independent of the bacteria type studied. The substrate- independent mussel-inspired immobilisation of zwitterionic peptides for the design of low-fouling surfaces provides a promising method for surface coating, and is of relevance for various applications, including drug delivery, biosensing and drug delivery.

\section{Acknowledgements}

This work was supported by the Australian Research Council under the Australian Laureate Fellowship (F.C., 120100030) and Discovery Project (F.C., 130101846) schemes. J.C. is the recipient of an Australian Research Council Super Science Fellowship (FS110200025). Dr Xiaofei Duan (Surface and Chemical Analysis Network in The University of Melbourne) is thanked for the help of XPS analysis and contact angle measurements.

\section{Notes and references}

Department of Chemical and Biomolecular Engineering, The University of Melbourne, Parkville, Victoria 3010, Australia. E-mail: fcaruso@unimelb.edu.au.

Electronic Supplementary Information (ESI) available: [XPS characterisation of PDA-coated and PDA/peptide-coated substrates, and contact angles of films formed on various substrates, and quantitative $E$. coli and $S$. epidermidis adhesion onto glass/PDA/PEG substrates after incubation for $24 \mathrm{~h}$.]. See DOI: 10.1039/b000000x/

1 M. K. Leung, C. E. Hagemeyer, A. P. Johnston, C. Gonzales, M. M. Kamphuis, K. Ardipradja, G. K. Such, K. Peter and F. Caruso, Angew. Chem. Int. Ed., 2012, 51, 7132-7136.

2 C. Nogues, H. Leh, J. Lautru, O. Delelis and M. Buckle, PLoS One, 2012, 7, e44287.

3 K. Vasilev, J. Cook and H. J. Griesser, Expert Rev. Med. Chem., 2009, 6, 553-567.

4 I. Banerjee, R. C. Pangule and R. S. Kane, Adv. Mater., 2011, 23, 690-718.

5 J. L. Dalsin, B.-H. Hu, B. P. Lee and P. B. Messersmith, J. Am. Chem. Soc., 2003, 125, 4253-4258.

6 V. Gaberc-Porekar, I. Zore, B. Podobnik and V. Menart, Curr. Opin. Drug Discovery Dev., 2008, 11, 242-250.

7 E. Ostuni, R. G. Chapman, R. E. Holmlin, S. Takayama and G. M. Whitesides, Langmuir, 2001, 17, 5605-5620.

8 L. Y. Li, S. F. Chen and S. Y. Jiang, J. Biomater. Sci.-Polym. Ed., 2007, 18, 1415-1427.

9 Q. Liu, A. Singh and L. Liu, Biomacromolecules, 2013, 14, 226-231.

10 S. Chen, L. Li, C. Zhao and J. Zheng, Polymer, 2010, 51, 5283-5293.

11 S. Jiang and Z. Cao, Adv. Mater., 2010, 22, 920-932.

12 R. Lalani and L. Liu, Biomacromolecules, 2012, 13, 18531863.

13 L. R. Carr, Y. Zhou, J. E. Krause, H. Xue and S. Jiang, Biomaterials, 2011, 32, 6893-6899.

14 W. Yang, L. Zhang, S. Wang, A. D. White and S. Jiang, Biomaterials, 2009, 30, 5617-5621.

15 L. Zhang, Z. Cao, Y. Li, J.-R. Ella-Menye, T. Bai and S. Jiang, ACS Nano, 2012, 6, 6681-6686. 
16 H.-W. Chien, C.-C. Tsai, W.-B. Tsai, M.-J. Wang, W.-H. Kuo, T.-C. Wei and S.-T. Huang, Colloids Surf. B, 2013, 107, 152159.

17 J. E. Rosen and F. X. Gu, Langmuir, 2011, 27, 10507-10513.

18 Q. Shi, Y. Su, W. Chen, J. Peng, L. Nie, L. Zhang and Z. Jiang, J. Membr. Sci., 2011, 366, 398-404.

19 S. Chen, Z. Cao and S. Jiang, Biomaterials, 2009, 30, 58925896.

20 A. K. Nowinski, F. Sun, A. D. White, A. J. Keefe and S. Jiang, J. Am. Chem. Soc., 2012, 134, 6000-6005.

21 P. L. Rodriguez, T. Harada, D. A. Christian, D. A. Pantano, R. K. Tsai and D. E. Discher, Science, 2013, 339, 971-975.

22 H. Lee, S. M. Dellatore, W. M. Miller and P. B. Messersmith, Science, 2007, 318, 426-430.

23 L. Q. Xu, W. J. Yang, K.-G. Neoh, E.-T. Kang and G. D. Fu, Macromolecules, 2010, 43, 8336-8339.

24 H. O. Ham, Z. Liu, K. H. A. Lau, H. Lee and P. B. Messersmith, Angew. Chem. Int. Ed., 2011, 50, 732-736.

25 H. Lee, J. Rho and P. B. Messersmith, Adv. Mater., 2009, 21, 431-434.

26 Q. Ye, F. Zhou and W. Liu, Chem. Soc. Rev., 2011, 40, 42444258.

27 A. Postma, Y. Yan, Y. Wang, A. N. Zelikin, E. Tjipto and F. Caruso, Chem. Mater., 2009, 21, 3042-3044.

28 J. Cui, Y. Wang, A. Postma, J. Hao, L. Hosta-Rigau and F. Caruso, Adv. Funct. Mater., 2010, 20, 1625-1631.

29 C. J. Ochs, T. Hong, G. K. Such, J. Cui, A. Postma and F. Caruso, Chem. Mater., 2011, 23, 3141-3143.

30 J. Cui, Y. Yan, G. K. Such, K. Liang, C. J. Ochs, A. Postma and F. Caruso, Biomacromolecules, 2012, 13, 2225-2228.

31 S. Hong, K. Y. Kim, H. J. Wook, S. Y. Park, K. D. Lee, D. Y. Lee and H. Lee, Nanomedicine, 2011, 6, 793-801.

32 S. H. Ku, J. Ryu, S. K. Hong, H. Lee and C. B. Park, Biomaterials, 2010, 31, 2535-2541.

33 G. Li, G. Cheng, H. Xue, S. Chen, F. Zhang and S. Jiang, Biomaterials, 2008, 29, 4592-4597.

34 C. Gao, G. Li, H. Xue, W. Yang, F. Zhang and S. Jiang, Biomaterials, 2010, 31, 1486-1492.

35 J. Kuang and P. B. Messersmith, Langmuir, 2012, 28, 72587266.

36 M.-C. Sin, Y.-M. Sun and Y. Chang, ACS Appl. Mater. Interfaces, 2014, 6, 861-873.

37 E. Tjipto, J. F. Quinn and F. Caruso, Langmuir, 2005, 21, 8785-8792.

38 B. Fei, B. Qian, Z. Yang, R. Wang, W. Liu, C. Mak and J. H. Xin, Carbon, 2008, 46, 1795-1797.

39 R. Liu, S. M. Mahurin, C. Li, R. R. Unocic, J. C. Idrobo, H. Gao, S. J. Pennycook and S. Dai, Angew. Chem. Int. Ed., 2011, 50, 6799-6802.

40 S. M. Kang, N. S. Hwang, J. Yeom, S. Y. Park, P. B. Messersmith, I. S. Choi, R. Langer, D. G. Anderson and H. Lee, Adv. Funct. Mater., 2012, 22, 2949-2955.

41 H. O. Ham, Z. Liu, K. H. Lau, H. Lee and P. B. Messersmith, Angew. Chem. Int. Ed., 2011, 50, 732-736.

42 J. Yu, W. Wei, E. Danner, R. K. Ashley, J. N. Israelachvili and J. H. Waite, Nat. Chem. Biol., 2011, 7, 588-590.

43 Q. Wei, F. Zhang, J. Li, B. Li and C. Zhao, Polym. Chem., 2010, 1, 1430-1433.

44 J. H. An, N. T. Huynh, Y. S. Jeon and J.-H. Kim, Polym. Int., 2011, 60, 1581-1586.

45 J. C. Hower, M. T. Bernards, S. Chen, H.-K. Tsao, Y.-J. Sheng and S. Jiang, J. Phys. Chem. B, 2009, 113, 197-201.

46 S. Herrwerth, W. Eck, S. Reinhardt and M. Grunze, J. Am. Chem. Soc., 2003, 125, 9359-9366.
47 L. Li, S. Chen, J. Zheng, B. D. Ratner and S. Jiang, J. Phys. Chem. B, 2005, 109, 2934-2941.

48 S. Chen, J. Zheng, L. Li and S. Jiang, J. Am. Chem. Soc., 2005, 127, 14473-14478.

49 S. M. Kang, J. Rho, I. S. Choi, P. B. Messersmith and H. Lee, J. Am. Chem. Soc., 2009, 131, 13224-13225. 


\section{University Library}

\section{- M M N E R VA A gateway to Melbourne's research publications}

Minerva Access is the Institutional Repository of The University of Melbourne

Author/s:

Cui, J;Ju, Y;Liang, K;Ejima, H;Loercher, S;Gause, KT;Richardson, JJ;Caruso, F

Title:

Nanoscale engineering of low-fouling surfaces through polydopamine immobilisation of zwitterionic peptides

Date:

2014-01-01

Citation:

Cui, J., Ju, Y., Liang, K., Ejima, H., Loercher, S., Gause, K. T., Richardson, J. J. \& Caruso, F. (2014). Nanoscale engineering of low-fouling surfaces through polydopamine immobilisation of zwitterionic peptides. SOFT MATTER, 10 (15), pp.2656-2663. https://doi.org/10.1039/ c3sm53056f.

Persistent Link:

http://hdl.handle.net/11343/123275 